
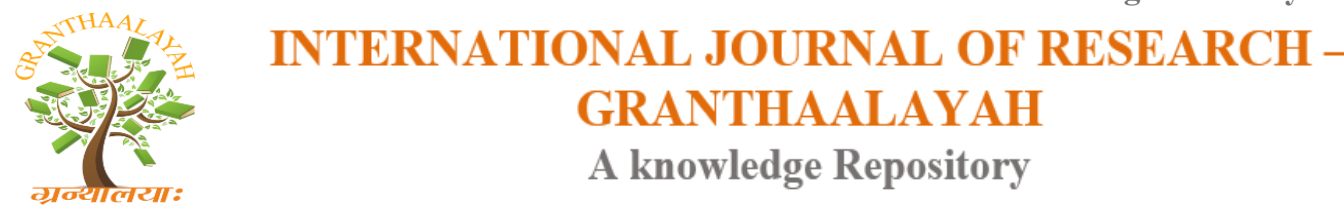

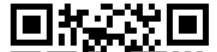

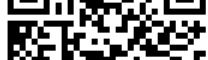

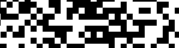

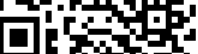

Management

\title{
A STUDY ON GRATIFICATION OF MIGRANT EMPLOYEES WITH SPECIAL REFERENCE TO TIRUPUR GARMENT INDUSTRY
}

\author{
T. Sreerekha ${ }^{* 1}$ \\ ${ }^{* 1}$ Assistant Professor, Management, NIFT - Tea College of Knitwear Fashion, Tirupur - 06, \\ INDIA
}

\begin{abstract}
"Quality of Work Life" is a term that had been used to describe the broader job-related experience an individual has. Quality of Work Life and major related concepts are gratification, workplace stress and quality of life. This study reveals that gratification is the major motivating factor responsible for Quality of work life. Gratification in the organization significantly differs from one organization to the other, one department to the other and even from one unit to the other depending upon the various factors influencing in the organization. Gratification and satisfaction refers to the result of various attitude possessed by an employee. The main objective of doing the study is to understand what job satisfaction means to employees. It helps to understand how good working conditions help employees to work more efficiently. It is all about employee involvement, which consists of methods to motivate employees to participate in decision making. This helps in building good relationships. This paper is a means to appreciate the nitty-gritty involved in employee's relationship with the organization and employers.
\end{abstract}

Keywords:

Quality of Work Life, gratification, job satisfaction, workplace stress and quality of life.

Cite This Article: T. Sreerekha, "A STUDY ON GRATIFICATION OF MIGRANT EMPLOYEES WITH SPECIAL REFERENCE TO TIRUPUR GARMENT INDUSTRY" International Journal of Research - Granthaalayah, Vol. 4, No. 3: SE (2016): 37-44.

\section{INTRODUCTION}

"Migrants keep moving forward, opening new doors and doing new things, because they are curious and curiosity leads them to new paths. They do their best, give their best and know that in doing so they will enhance the quality of their work life".

Migration is a process of movement of an individual or a group of people from one region to another. Interstate migration is a livelihood strategy; people have started to cross the boundaries in search of better job opportunities. Today, the textiles industry has an overwhelming presence in the economic life of India. It plays a pivotal role through its contribution to industrial output, 
employment generation, and the export earnings of the country. Most of the employees in garment sectors are migrants. Garment exporters are adopting long run strategies to achieve greater sophistication in planning and flexibility in operations to respond quickly to market shifts through migrated workers. Migrated workers are right choice to the Garments exporters for establishing their manufacture schedules closer to the selling period based on quick response strategy that links apparel retailing and manufacturing operations to make available the right product at right time. The main push factors influencing the internal migration are water logging, famine, drought, land fragmentation, river bank erosion, family and personal problems. The main pull factors are the desire to earn more, to acquire new skills, to gain new experiences, the thirst of freedom and equality. The violations of the rights of migrant workers start at home by agents and agencies of recruitment in the sending states. As many of the migrant workers come from rural region these migrant have very little access to and knowledge of pre-departure information. The migrant workers are facing some common problems like, poor accommodations, work without holidays, lack of health care, food problems, seizure of personal documents, contract substitution, irregular job placement, low wage rates, pathetic work conditions and lack of payment for overtime. Wages for migrant workers vary from sector to sector and region to region. Hence this study aims to find out the gratification and satisfaction of migrant employees in Tirupur garment industry.

\section{JOB SATISFACTION}

The major related concept of Quality of Working Life is Job satisfaction. Satisfaction is a psychological factor. It cannot be seen and cannot quantify. But its expression in human mind is understandable. When an employee is satisfied with his assigned task and can discharge his actions satisfactorily, it is called 'job satisfaction'. It is the combination of psychological, physiological and environmental circumstances that cause a person to truthfully say, "I am satisfied with my job". Employees job satisfaction can be promoted by providing them with rewards, job security and growth opportunities.

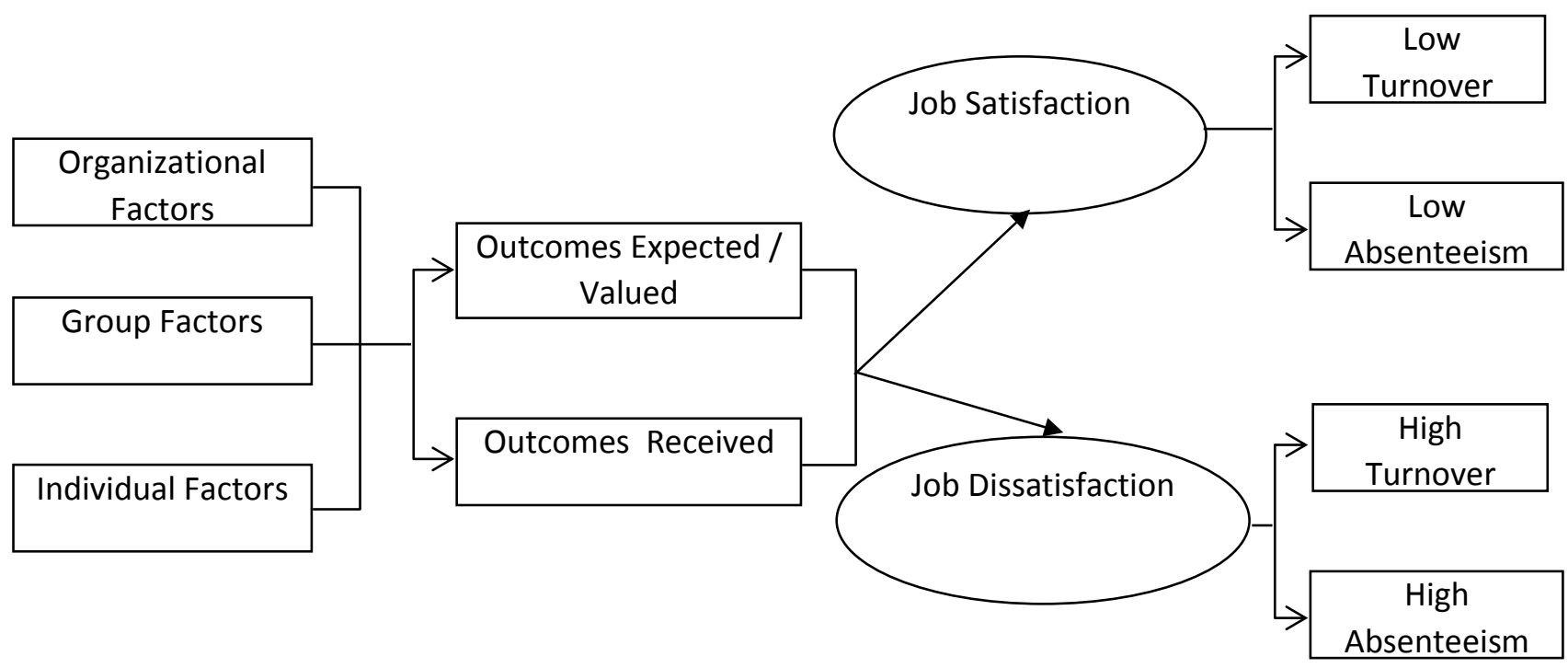




\section{STATEMENT OF THE PROBLEM}

Tirupur is facing a crisis in terms of excessive mobile population as well as frequent migrants from other parts of the State and the country. The basic infrastructure facilities like roads, drinking water, recreational space, adequate housing for migrant workers are missing adding further woes for workforce which survives in an already dampened working conditions in most of the small and medium knitting, stitching, packing, compacting, dyeing and bleaching units of this region. Migrant worker's wages and expenditures are not in balance, so often they fall in debt. Expenditures in terms of drinking water during summer, payment of rent during off season or low garment production seasons, children's education, frequent shifting of house on account of rising house rent and medical expenses due to both work related physical stress. Also, the enrollment rates of migrant workers under ESI scheme is very low compared to the regular workers from the same city. This will further insist on the necessity for conducting a research for improving the status of migrant workers in the garment city. This study is an attempt to know about the job satisfaction of the migrant employees in Tirupur City.

\section{OBJECTIVES OF THE STUDY}

1) To study the demographic factors of the migrant employees working in the Tirupur garment industry.

2) To study the various factors those are influencing the job satisfaction and in turn influencing the quality work life of migrant employees in Tirupur city.

3) To study the problems faced by the migrant employees in the Tirupur garment industry.

4) To offer suggestions and recommendations to enrich the job satisfaction among the migrant garment employees in Tirupur City

\section{RESEARCH METHODOLOGY}

The research design used for the study is a descriptive research design. The main characteristic of this method is that the researcher has no control over the variables. It is only record of the feeling of employees towards their work life.

In this study non-probability sampling procedure is used, under this convenience sampling method is adopted. The total sample size constitutes of 300 migrant garment employees in Tirupur City.

\begin{tabular}{|l|l|}
\hline Data source & Primary data \\
\hline Research Approach & Survey \\
\hline Research Instrument & Interview Schedule cum Questionnaire \\
\hline Method of Conduct & Personal \\
\hline
\end{tabular}

\section{Tools for analysis:}

The primary and secondary data were presented in the form of tables and these tables were systematically analyzed with the aid of some statistical techniques like percentage, weighted average and Henry Garrett Ranking Technique. 


\section{Limitations of the study:}

The management has not allowed the researcher to collect the information from the night shift operators. The opportunities are very limited to get the data from night shift employees.

This research includes only the middle level and low level migrant employees of the garment industry. The research sample does not include the high level employees.

\section{REVIEW OF LITERATURE}

Shapiro et.al.(1974) ${ }^{1}$, studied job satisfaction as measured by the Job Description Index (JDI), of seventy-five employees in a steel manufacturing concerns. The results indicated that Taylor's concept of money as a prime motivation of human efforts was still avoidable hypothesis. It was concluded that employees were not highly motivated by social, self-esteem, self-actualization (or) work associated needs.

Dreher $(\mathbf{1 9 8 0})^{2}$, found that satisfaction on similar jobs may vary because employees desires and values may differ. It was found in a large nationwide oil company, that satisfaction among managers, professional and technical employees varied depending on characteristics of the community, in which the employees lived, sex through the type of work and company policies were roughly comparable across the communities.

Rai et.al.(1987) ${ }^{3}$, in their study on personality determinants of job satisfaction of college teachers reported that job satisfaction depends upon a variety of factors, internal and external conditions of work life salary, advancement, recognition, feeling of achievements, responsibility dealing of the boss, relation with colleagues, boss and students, financial return and attitude of management.

Dr.S.P.Bansal (2000) ${ }^{4}$, in his study the job satisfaction among bank employees of public sector and cooperative banks in Shimla town were discussed. He analyzed the job satisfaction of the employees with regard to the performance of organizing their attitude morale. The study concluded that a significant relationship existed between the given salary and job satisfaction. The officers belonging to rural back ground were more satisfied as compared to urban cities due to their fewer needs.

Shiv Mohan et.al. (2012) ${ }^{\mathbf{5}}$, job satisfaction and quality of work life go hand in hand when talked about real satisfaction since one is the outcome of other. The basic objective of the study was to determine the gender difference in term of satisfaction with quality of work life between male and female workers. Also attempt is made to measure the level of quality of work life among the employees is made. It focus on measures like job monotony, un clarity in goals, employee attrition, and role stress need to be properly handled.

\section{DATA ANALYSIS AND FINDINGS}

Table 1: Demographic factors

\begin{tabular}{|l|l|l|l|}
\hline S.NO & \multirow{2}{*}{ VARIABLES } & CLASSES & PERCENTAGE \\
\hline \multirow{3}{*}{1.} & \multirow{2}{*}{ AGE } & Below 20 & 19 \\
\cline { 3 - 4 } & & $21-40$ & 52 \\
\cline { 3 - 4 } 2. & \multirow{2}{*}{ GENDER } & Above 40 & 29 \\
\hline \multirow{2}{*}{3.} & \multirow{2}{*}{ MARITAL STATUS } & Fale & 45 \\
\cline { 3 - 4 } & & Female & 55 \\
\cline { 3 - 4 } & & Married & 59 \\
\hline
\end{tabular}




\begin{tabular}{|c|c|c|c|}
\hline & & Widowed & 7 \\
\hline & & Separated & 3 \\
\hline & & No Formal Education & 25 \\
\hline 4. & EDUCATIONAL & Higher Secondary & 39 \\
\hline & & Diploma/UG & 36 \\
\hline & & Below 5,000 & 22 \\
\hline 5 & MONTHL Y INCOME & $5,001-10,000$ & 20 \\
\hline 5 & MUNAHLY INCOME & $10,001-15,000$ & 12 \\
\hline & & Above 15,000 & 46 \\
\hline & & Below 5 Years & 52 \\
\hline 6 & WORKEXPERIENCE & 6-10 Years & 40 \\
\hline & & Above 10 Years & 8 \\
\hline
\end{tabular}

Source: Primary data

The above table shows that the majority 52 percent of the respondents were in the age group of 21-40, 55 percent of the respondents are female, 59 percent of the respondents are married, 39 percent of the respondents are higher secondary, 46 percent of the respondents monthly income was above 15,000, 52 percent of the respondents had working experience below 5 years.

Table 2: Weighted average Gratification and satisfaction of migrant garment employees in

\begin{tabular}{|l|l|}
\multicolumn{2}{c}{ Tirupur city } \\
\hline FACTORS & TOTAL SCORE \\
\hline Present Job & 4.10 \\
\hline Training \& Development & 3.57 \\
\hline Grievance handling & 3.73 \\
\hline Job sharing method & 3.81 \\
\hline Safety measures & 3.96 \\
\hline Welfare measures & 3.69 \\
\hline Leave facilities & 3.06 \\
\hline Resting time & 3.11 \\
\hline Incentives & 3.16 \\
\hline Bonus & 2.69 \\
\hline Motivation & 3.45 \\
\hline TOTAL & $38.33 / 11=3.48$ \\
\hline
\end{tabular}

Source: Primary data

\section{Mean score $=3.48$}

The details of Job gratification and satisfaction of migrant employees are presented in the above table the mean score value is 3.48 .

From the above table it can be inferred that the mean score is 3.48. Factors such as present job, training \& development, grievance handling, job sharing method, safety measures, and welfare measures are score above 3.48 Such as 4.1, 3.57, 3.73, 3.81, 3.96, and 3.69 respectively. Hence the respondents found these attributes to be highly satisfactory. 
The factors such as leave facilities, resting time, incentives, bonus and motivation are below 3.48 such as 3.06, 3.11, 3.16, 2.69 and 3.45 respectively therefore these factors are dissatisfied by the respondents.

Table 3: HENRY GARRETT RANKING TECHNIQUE

Problems faced by the migrant employees

\begin{tabular}{|l|l|l|l|l|}
\hline $\begin{array}{l}\text { S. } \\
\text { No }\end{array}$ & $\begin{array}{l}\text { Problems faced by the migrant } \\
\text { employees }\end{array}$ & $\begin{array}{l}\text { TOTAL GARRETT } \\
\text { SCORE }\end{array}$ & $\begin{array}{l}\text { Mean } \\
\text { score }\end{array}$ & RANK \\
\hline 1 & Timings & 5077 & 50.8 & IV \\
\hline 2 & Work Overload & 5448 & 54.5 & III \\
\hline 3 & Family problems & 5761 & 57.6 & I \\
\hline 4 & Health, physical \& mental harassment & 5639 & 56.4 & II \\
\hline 5 & Management Problems & 3897 & 39.0 & VI \\
\hline 6 & Shift Problems & 4065 & 40.7 & V \\
\hline
\end{tabular}

Most of the respondents are having family problems which ranked first by the employee with total score of 5761 points.

\section{SUGGESTIONS}

\section{Suggestions for the gratification Factors}

- Training and development should be routine in the company environment. Regular training program will help the employees to improve the technical skills and in turn increase the job satisfaction.

- Employee's problems can be solved by grievance procedure. It provides employees a formalized means of emotional release for their dissatisfactions. Even if a worker does not use the grievance system for his own emotional release in a particular situation, he feels better because he knows the system is there to use if he wants to do so. It builds within him a sense of emotional security and helps to increase the employee empowerment in Organization.

- To promote human relations, the work environment should be able to meet the needs of its workers such as minimum control and supervision, opportunity for maximum expression of one's abilities and skills, detailed knowledge about one self and about job.

- The quality of company functions will be improved, when its member's functions as groups under participative management and job sharing method.

- During the production the supervisors can ask workers about their own ideas in doing the particular work apart from the regular process followed in the company, it leads to the workers to be loyal to the management.

- Regular Break intervals and flexibility of work schedule should be assigned to the employees. If the organizations are willing to provide the refreshment to the workers, then 20 minutes can be save per day, by avoiding the slow starting of the works. 
- The existing leave and salary procedure needs a review. Company could provide a leave calendar to each and every employee with assigned leave on pay, casual leave, medical leave and maternity leave in case of female employees.

- Performance appraisal method can be followed for evaluating the employees. It can be measured by individual performance, team work, sectional productivity, etc. For avoiding the monetary issues company could revise the salary in the regular intervals.

- Giving awards and rewards to the workers for their best performance can do motivation.

\section{Suggestions for the problems faced by the migrant employees}

- The minimum basic wage per day for all types of workers should be based on 8 hours per day. In Tirupur garment industry work shifts are scheduled on a 12-hour basis, called $11 \frac{1}{2}$ shifts. Owing to break times, the actual work time during these 12 hours is about 10.5 hours. Workers are usually paid in accordance with their number of shifts, which ignores the fact that 2.5 hours of each day are entitled to $200 \%$ pay. There is no use of overtime wage rates and this system leads to workers being underpaid for overtime by about $20 \%$.

- A separate cell to prevent sexual harassment should be constituted. Employers should ensure that the benefits and welfare schemes under the labour laws reach all the workers.

- Overtime wages should be paid for all the time rate and piece rate workers. Death of any worker during the tenure of employment should be paid with a compensation amount to workers' family by the employer.

\section{SCOPE FOR FURTHER RESEARCH}

This project made an attempt to study the gratification of migrant employees in garment industry with special reference to Tirupur City. Also, it is possible to extend the research for migrant male and migrant female employees, concentrating on each gender by analyzing the migration impact on their life separately. There is a wide scope for the further migration study from the people moving from villages to cities, cities to states, states to countries, national to international level and vice versa. The impact of garment industry in the psychological, physiological, Welfare and social well-being of the migrant employees, the role of migrant employee participation in the concerned industry for the economic development of our country and the global economic impact for the same could be considered in detail for further analysis and Research.

\section{CONCLUSION}

A study on gratification and satisfaction of migrant employees in the garment industry is the degree to which the employees in an organization feel safety, security and satisfaction with various factors. The study is most useful to determine the job satisfaction factors affecting the migrant employees in the Garment industry. When migrant labour is hired in a formal way with formal contract it gives safety and security. But when they are hired in an informal and casual way it results in low pay, insecurity and poor conditions. In the whole study about the garment industry in Tirupur city the researcher found overall management welfare measures was satisfactory in nature. Minor changes need in the point of migrant employee well wish. Only smaller level of administration reforms are needed in overall observation. 


\section{REFERENCES}

[1] Shapiro, H.J, Wahba, M.A., "Fredick.W. Taylor, "62 years later”, Personnel Journal, vol.53, 1974, pp.574-578.

[2] Dreher, G.E., "Salary Satisfaction and Community Costs", Journal of Industrial Relations, vol.19, 1980, pp.340-344.

[3] Rai, D and Bhatt, J., "Personality Determinants and Job Satisfaction of College Teachers in the Sourashtra Region of Gujarat State”, Dissertation Abstract International, vol.47, 1987, pp.32-37.

[4] Dr.S.P.Bansal , "Job satisfaction among bank employees. A study of public sector of cooperative banks in Shimla town”, India cooperative review national union of trade India, New Delhi, Jan 2000 Vol.xxxvii, Issue 3, p. 138.

[5] Shiv Mohan, ArtiKansal, "Job satisfaction and Job Stress; A study of the Hotel Industry in Delhi” ,H.R. Journal of Management, Oct 2012 - March 2013, vol,5, Issue 2, pp.96102, ISSN No 0974-7737.

[6] Khanka, S.S., Human Resource Management, New Delhi, Sultan Chand \& Company Ltd., 2003.

[7] Kothari, C.R., Research Methodology, New Delhi, New age international limited., 2004.

[8] Ann Davis, Lucy Gibson, "Designing Employee Welfare Provision", Personnel Review, vol. 23 Issue.7, January2012,pp.33-45.

[9] Uma Rani, H.S. Shylendra, 'Seasonal Migration and Rural-Urban Interface in Semi-Arid Tropics of Gujarat: A Study of Tribal Village', Journal of Rural Development, vol.20, Issue 2, 2001, pp. 187-217.

[10] Jelince Dhinakar Abraham (2009), Ph.D. thesis titled, "A study on the role and role ability of merchandisers in the knit wear export firms of Tirupur district”, Submitted to Bharathiar University, Coimbatore.

[11] www.Scribd.com

[12] www.wikipedia.org

[13] www.citehr.com

[14] www.studymode.com

[15] www.academicjournals.com 